MOUTINHO, E.P.M. et al. Efeito de diferentes antibióticos na composição do diluente, sobre a viabilidade do sêmen suíno refrigerado. PUBVET, Londrina, V. 5, N. 19, Ed. 166, Art. 1121, 2011.

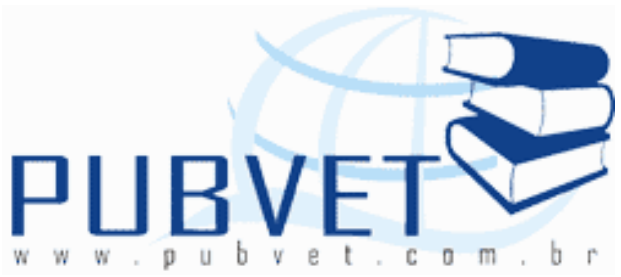

PUBVET, Publicações em Medicina Veterinária e Zootecnia.

\title{
Efeito de diferentes antibióticos na composição do diluente, sobre a viabilidade do sêmen suíno refrigerado ${ }^{1}$
}

\section{Elen de Paula Matias Moutinho²; Karen Martins Leão ${ }^{3}$; Rossane Pereira da Silva²; Natália do Carmo Silva²; Moraima Castro Rodrigues²; Marco Antônio Pereira da Silva ${ }^{4}$}

${ }^{1}$ Trabalho apresentado pela primeira autora como parte das exigências para conclusão do curso de bacharelado de Zootecnia do Instituto Federal de Educação, Ciência e Tecnologia Goiano - Campus Rio Verde

${ }^{2}$ Zootecnista pelo Instituto Federal de Educação, Ciência e Tecnologia Goiano Campus Rio Verde;

${ }^{3}$ Médica Veterinária, Profa. Dra. do Instituto Federal de Educação, Ciência e Tecnologia Goiano - Campus Rio Verde;

${ }^{4}$ Zootecnista, Prof. Dr. do Instituto Federal de Educação, Ciência e Tecnologia Goiano - Campus Rio Verde.

\section{Resumo}

O objetivo do trabalho foi avaliar o efeito de diferentes antibióticos (Cloridrato de Ceftiofur, Sulfato de Estreptomicina e Sulfato de Gentamicina) na composição do diluente, sobre a viabilidade espermática e crescimento bacteriano do sêmen refrigerado de reprodutores suínos. Experimento 1: Após a colheita, o ejaculado filtrado foi diluído para uma concentração de $50 \times 10^{6}$ espermatozóides por $\mathrm{mL}$, e posteriormente à diluição, no momento T0 avaliou- 
MOUTINHO, E.P.M. et al. Efeito de diferentes antibióticos na composição do diluente, sobre a viabilidade do sêmen suíno refrigerado. PUBVET, Londrina, V. 5, N. 19, Ed. 166, Art. 1121, 2011.

se motilidade total (\%), motilidade progressiva (\%) e vigor (0 - 5). As amostras foram refrigeradas a $17^{\circ} \mathrm{C}$ em três tratamentos: Tratamento I sêmen diluído com Proli-Max ${ }^{\circledR}$ e Cloridrato de Ceftiofur; Tratamento II - sêmen diluído com Proli-Max ${ }^{\circledR}$ e Sulfato de Estreptomicina; Tratamento III - sêmen diluído com Proli-Max ${ }^{\circledR}$ e Sulfato de Gentamicina. Novas avaliações foram realizadas com 24, 48 e 72 horas de refrigeração, após aquecimento das amostras em banho-maria a $37^{\circ} \mathrm{C}$ por 10 minutos. Experimento 2: Foi inoculado 100 microlitros de uma amostra de sêmen refrigerado por zero, 24, 48, e 72 horas em placas de Petri de acordo com os grupos: Grupo I - sem antibiótico; Grupo II - Cloridrato de Ceftiofur; Grupo III - Sulfato de Estreptomicina e Grupo IV - Sulfato de Gentamicina. As placas foram mantidas em estufa a $37^{\circ} \mathrm{C}$ por um período de 48 horas para observação de crescimento de colônias de bactérias. Os resultados demonstraram que o antibiótico Sulfato de Gentamicina apresentou uma menor eficiência para a manutenção da viabilidade espermática até 72 horas de refrigeração e demonstrou ser o melhor para o controle do crescimento bacteriano no sêmen de reprodutores suínos.

Palavras-chave: sêmen refrigerado, suínos, antibióticos.

\title{
Effect of antibiotics different in the composition of the diluent, on the viability of the cooled swine semen
}

\begin{abstract}
The objective of the work were evaluate the antibiotic different effect (ceftiofur chloridrate, streptomycin sulphate and gentamicin sulphate) in the composition of diluent, on the spermatic viability and bacterial growth of the cooled swine semen. The results demonstrated that the antibiotic gentamicin sulphate presented minor efficiency in the maintenance of the spermatic viability up to 72 hours of refrigeration and demonstrated optimum for the control of the bacterial growth in the swine semen.
\end{abstract}

Keywords: cooled semen, swines, antibiotics. 
MOUTINHO, E.P.M. et al. Efeito de diferentes antibióticos na composição do diluente, sobre a viabilidade do sêmen suíno refrigerado. PUBVET, Londrina, V. 5, N. 19, Ed. 166, Art. 1121, 2011.

\section{INTRODUÇÃO}

A manutenção do sêmen suíno sob condições de refrigeração tem se mostrado uma técnica eficiente para a difusão de material genético através dos programas de inseminação artificial. Quando o sêmen é adequadamente processado e armazenado, é possível a obtenção de ótimos resultados de prenhez e de tamanho de leitegada utilizando sêmen refrigerado. Muitas vezes, o sêmen coletado é de excelente qualidade, mas erros de coleta, processamento, armazenamento ou transporte podem reduzir ou comprometer o potencial fecundante dos espermatozóides, acarretando quedas na fertilidade do rebanho (FERREIRA et al., 2005).

O ejaculado, aparentemente, tem um papel pouco importante na disseminação das bactérias contaminantes do sêmen após a inseminação artificial (IA), uma vez que, por meio da inclusão de uma combinação de antibióticos, pode-se prevenir a transmissão desses agentes bacterianos (SCHEID, 2000). Porém, isso de forma alguma significa que as medidas de higiene referentes às instalações, alojamento e cuidado com os animais, colheita, processamento, armazenamento, distribuição e utilização do sêmen possam ser negligenciadas.

A presença de contaminação bacteriana no ejaculado pode ser originária de uma infecção sistêmica ou infecção do sistema reprodutivo, bem como do contato do ejaculado com secreções prepuciais, pêlos, mãos do funcionário, contato indireto com aerossóis, contaminação dos materiais e equipamentos utilizados na colheita (fômites), diluição e acondicionamento do sêmen (MAZUROVA \& KRPATOVA, 1990). Desse modo, as fases críticas para a qualidade bacteriológica do sêmen são: colheita, manipulação e conservação do ejaculado.

Os microrganismos podem afetar diretamente o espermatozóide devido à competição pela utilização de nutrientes naturais do sêmen, causar lesões na célula por aderência à membrana plasmática ou por metabólitos tóxicos liberados no meio, bem como infectar a fêmea, resultando assim em baixas 
MOUTINHO, E.P.M. et al. Efeito de diferentes antibióticos na composição do diluente, sobre a viabilidade do sêmen suíno refrigerado. PUBVET, Londrina, V. 5, N. 19, Ed. 166, Art. 1121, 2011.

taxas de concepção (FERREIRA et al., 2005). Muitos microrganismos podem localizar-se na cavidade prepucial do reprodutor, tais como: Bacillus sp, Pseudomonas, Streptococcus sp. O protocolo "Técnica de mínima contaminação" é um exemplo de procedimento desenvolvido para o controle da contaminação do sêmen diluído, e abrange desde a fase pré-colheita, colheita, preparação do sêmen, e limpeza do laboratório (ALTHOUSE et al., 2000).

O adequado treinamento da equipe da Central de Inseminação Artificial (CIA) influencia na produtividade do setor, inicialmente pela adequada colheita do sêmen, evitando perdas de parte do ejaculado, cuidados durante a execução da colheita de modo a reduzir ao máximo a contaminação do sêmen, e posteriormente na decisão de descartar adequadamente os ejaculados impróprios para diluição, durante a avaliação dentro do laboratório (BORTOLOZZO et al., 2005). O emprego de materiais descartáveis, desde a colheita até a infusão da dose inseminante, proporcionam um menor nível de contaminação do sêmen, tanto biológicamente (bactérias) como químicamente (resíduos de detergente provenientes da lavagem, por exemplo), melhorando a qualidade da dose inseminante (BORTOLOZZO et al., 2002).

A principal conseqüência da contaminação do sêmen é a redução do período de sobrevivência espermática, ocasionando transtornos à operação dos programas de Inseminação Artificial. A presença de bactérias pode causar significativa redução da motilidade, aglutinação espermática, alterações secundárias de acrossoma e morte das células ocorrendo dentro de dois dias após a colheita e processamento do sêmen, independentemente do diluente utilizado (ALTHOUSE et al., 2000).

Constata-se na flora do sêmen e prepúcio de outras espécies, de animais como bovinos e búfalos, aparentemente sadios, a presença de bactérias, como Bacillus sp, Staphylococcus sp, Corynebacterium sp e Streptococcus sp (RODRIGUES et al., 1999).

A monitoria bacteriológica periódica do sêmen, imediatamente após a coleta e em diferentes períodos do processamento e conservação do ejaculado, 
MOUTINHO, E.P.M. et al. Efeito de diferentes antibióticos na composição do diluente, sobre a viabilidade do sêmen suíno refrigerado. PUBVET, Londrina, V. 5, N. 19, Ed. 166, Art. 1121, 2011.

é um procedimento recomendado para avaliação do grau de contaminação nas CIAs, indicando a necessidade de mudanças ou correção dos procedimentos adotados (ALTHOUSE \& LU, 2005). Dessa forma, deve-se evitar que o ejaculado contaminado seja destinado para a inseminação antes que sinais clínicos da doença sejam reconhecidos e o diagnóstico definitivo seja estabelecido (WEITZE, 1996).

O armazenamento prolongado, em condições de resfriamento, pode afetar profundamente a qualidade das células espermáticas, uma vez que condições anaeróbicas associadas à contaminação microbiana reduzem a motilidade e a viabilidade espermáticas (RURANGWA et al., 2004). Segundo Stoss \& Donaldson (1982), os fatores mais determinantes do sucesso do resfriamento são: redução da temperatura, fornecimento e troca de gases, e prevenção do desenvolvimento bacteriano.

Segundo Perestrelo-Vieira \& Perestrelo-Vieira (1995), as bactérias provocam, geralmente, poucos problemas reprodutivos após a inseminação, quando estão presentes em pequenas quantidades (10 UFC/mL de sêmen diluído), embora constituam um fator de risco em relação à fertilidade e à prolificidade da fêmea.

As medidas de higiene visam reduzir ao mínimo possível a contaminação por microrganismos normalmente presente nos animais, pessoas e ambiente, mas não são capazes de eliminá-la totalmente. Por essa razão, são adicionados antibióticos ao diluente. Antibióticos normalmente utilizados para esse fim apresentam ausência de espermotoxicidade, porém devem possuir ação antimicrobiana eficaz, preferencialmente de amplo espectro (CORRÊA et al., 2001).

Vários agentes antimicrobianos, dentre eles gentamicina, penicilina, estreptomicina, têm sido utilizados nos diluentes comerciais para controlar ou inibir o crescimento bacteriano, uma vez que a temperatura na qual as doses inseminantes são estocadas não é capaz de impedi-lo (FERREIRA et al., 2005).

Alguns microrganismos encontrados em amostras de sêmen de reprodutores caprinos, apresentaram resistência à penicilina e estreptomicina, 
MOUTINHO, E.P.M. et al. Efeito de diferentes antibióticos na composição do diluente, sobre a viabilidade do sêmen suíno refrigerado. PUBVET, Londrina, V. 5, N. 19, Ed. 166, Art. 1121, 2011.

associação amplamente utilizada nos diluidores de sêmen. Em contrapartida, a gentamicina apresenta maior eficiência no controle efetivo de microrganismos, sendo, portanto uma alternativa a ser recomendada, na concentração de 13,3 $\mathrm{mg} / \mathrm{mL}$ no processamento de doses inseminantes (COELHO, 1976).

Embora o emprego de alguns antimicrobianos traga prejuízos à motilidade espermática, o seu uso reduz o número de unidades formadoras de colônias nas doses produzidas (BORTOLLOZO et al., 2000).

$O$ objetivo do presente trabalho foi avaliar o efeito de diferentes antibióticos, Cloridrato de Ceftiofur, Sulfato de Estreptomicina e Sulfato de Gentamicina, na composição do diluente, sobre a viabilidade espermática e crescimento bacteriano do sêmen de varrões refrigerado.

\section{REVISÃO DE LITERATURA}

\subsection{Características do Sêmen de Varrão}

O espermatozóide suíno é um dos mais sensíveis ao choque térmico, quando comparado aos de outras espécies. Vários fatores podem estar envolvidos na susceptibilidade dos espermatozóides suínos ao choque térmico, merecendo ênfase a forma da cabeça. A forma da cabeça dos espermatozóides poderia ser uma das razões para a diferença de sensibilidade ao choque térmico entre as espécies. Assim, espermatozóides com cabeças grandes e achatadas, como as observadas na espécie suína, seriam mais sensíveis do que os com cabeças menores e mais compactas (WATSON \& PLUMMER, 1985).

O conhecimento profundo da estrutura e do funcionamento da membrana plasmática dos espermatozóides é ponto inicial para o êxito dos processos de manipulação do sêmen, principalmente, tratando-se de espécies como a suína, cujas células apresentam baixa resistência ao choque térmico. A estrutura básica da membrana plasmática de qualquer espécie é o mosaico fluido, constituído por dupla camada lipídica entremeada por moléculas de proteínas. A estrutura da bicamada lipídica é composta por $65 \%$ a $70 \%$ de 
MOUTINHO, E.P.M. et al. Efeito de diferentes antibióticos na composição do diluente, sobre a viabilidade do sêmen suíno refrigerado. PUBVET, Londrina, V. 5, N. 19, Ed. 166, Art. 1121, 2011.

fosfolipídios, sendo o ácido docosahexanóico (DHA) o principal ácido graxo ligado a estes fosfolipídios, conferindo fluidez à membrana (HOLT, 2000).

Qualquer dano ocorrido no acrossoma pode inibir a capacidade fecundante do espermatozóide, uma vez que ejaculados suínos com elevado percentual de acrossomas anormais tem mostrado reduzir a fertilidade dos animais (PURSEL et al.,1972a).

Os lipídios encontram-se normalmente na fase fluida na temperatura denominada de fase de transição ( $\mathrm{Tm})$, que permite movimentação na camada bilaminar. Se a temperatura encontra-se abaixo da temperatura de transição, como no congelamento, ela é chamada de fase gel, tornando os lipídeos imóveis. Sabe-se que a fase de transição é específica para cada classe de lipídio, portanto, à mesma temperatura, regiões diferentes da membrana podem estar na forma fluida ou gel. A excessiva formação da fase gel pode resultar em agrupamento das proteínas de membrana. Além disso, o resfriamento pode resultar em lesões de membrana irreversíveis (GADELLA, 1996).

Fatores individuais influenciam a qualidade da dose inseminante (DI) e, conseqüentemente, o desempenho reprodutivo de granjas suínas que empregam a Inseminação Artificial (IA). Estudos têm demonstrado que existem variações individuais na fertilidade e no período de preservação do sêmen de diferentes machos suínos (WEITZE, 1990a), o que torna a sua seleção pela qualidade do sêmen um fator importante para o sucesso dos processos de refrigeração.

Uma das condições essenciais para a produção de ejaculados férteis, com grande quantidade de espermatozóides móveis e com percentual aceitável de células anormais, é o controle da temperatura no local de alojamento dos animais. Machos submetidos a $30^{\circ} \mathrm{C}$ (STONE, 1982) por três dias (MCNITT \& FIRST, 1970) apresentaram aumento no percentual de alterações na morfologia espermática. Machos mantidos em temperaturas entre $26^{\circ} \mathrm{C}$ e $29^{\circ} \mathrm{C}$ por cinco a seis semanas apresentaram um aumento no número de ejaculados 
MOUTINHO, E.P.M. et al. Efeito de diferentes antibióticos na composição do diluente, sobre a viabilidade do sêmen suíno refrigerado. PUBVET, Londrina, V. 5, N. 19, Ed. 166, Art. 1121, 2011.

rejeitados por baixa qualidade, resultando em uma diminuição do número de doses produzidas por macho alojado (FLOWERS, 1997).

\subsection{Diluidores de Sêmen Suíno}

Os diluentes de sêmen são compostos com uma ampla variedade de substâncias quimicamente diferentes entre si (açúcares, substâncias tampões, antibióticos), que têm a finalidade de manter os espermatozóides viáveis até o momento de serem introduzidos no trato genital da fêmea (FERREIRA et al., 2005).

O termo diluidor, ou extensor, refere-se a uma solução aquosa que possui várias funções, tais como a de aumentar o volume do ejaculado total, fornecer nutrientes para a produção de energia, proteger os espermatozóides contra o choque térmico, controlar a flutuação de $\mathrm{pH}$, manter o balanço osmótico, inibir o desenvolvimento bacteriano (JOHNSON et al., 2000; LEVIS, 2000) e preservar as características funcionais das células espermáticas, favorecendo a obtenção de taxas de prenhez adequadas (GADEA, 2003).

Atualmente, há dois grupos de diluidores, chamados diluidores de curta e de longa duração, conforme o período de tempo que conseguem preservar o sêmen, com manutenção de características espermáticas e fertilidade adequada (BRAGA, 2007).

Os diluidores de curta duração preservam o sêmen por um a três dias e são usados principalmente nas granjas que possuem uma central de IA, sendo o sêmen utilizado dentro de 24 horas após a coleta, seja na própria granja ou em granjas próximas. São exemplos os diluidores Illinois Variable Temperature (IVT), Kiev, Beltsville Thawing Solution (BTS) e o Bestsville Liquid (BL-1) (GADEA, 2003).

Os diluidores de longa duração preservam o sêmen por mais de quatro dias e são utilizados quando o sêmen tem que ser transportado a longas distâncias entre a central de inseminação e a granja, como é o caso da Noruega, onde uma central distribui o sêmen para todo o território nacional, com isso, a central tem maior controle da freqüência de coletas de sêmen, 
MOUTINHO, E.P.M. et al. Efeito de diferentes antibióticos na composição do diluente, sobre a viabilidade do sêmen suíno refrigerado. PUBVET, Londrina, V. 5, N. 19, Ed. 166, Art. 1121, 2011.

deixando-o armazenado por um maior período de tempo (GADEA, 2003). A composição dos principais diluentes utilizados na IA de suínos está apresentada na Tabela 1.

TABELA 1 - Composição, em gramas, dos principais diluentes utilizados na IA de suínos.

\begin{tabular}{|c|c|c|c|c|c|}
\hline \multirow[b]{3}{*}{ Componente (g) } & \multicolumn{5}{|c|}{ Tipos de Diluente } \\
\hline & \multicolumn{2}{|c|}{ Curta Duração } & \multicolumn{3}{|c|}{ Longa Duração } \\
\hline & BTS & KIEW & Reading & Androhep & MR-A* \\
\hline Glicose Anidra & 37,0 & 60,0 & 11,5 & 26,0 & + \\
\hline $\begin{array}{l}\text { Citrato de Sódio } \\
\text { Bicarbonato de }\end{array}$ & 6,0 & 3,75 & 11,65 & 8,0 & + \\
\hline Sódio & 1,25 & 1,25 & 1,75 & 1,2 & + \\
\hline EDTA & 1,25 & 3,7 & 2,35 & 2,4 & + \\
\hline Cloreto de & & & & & \\
\hline $\begin{array}{l}\text { Potássio } \\
\text { Acetato de }\end{array}$ & 0,75 & - & 0,75 & - & - \\
\hline Potássio & - & & & & + \\
\hline Tampão TRIS & - & - & 5,5 & - & - \\
\hline Ácido Cítrico & - & - & 4,1 & - & - \\
\hline Cisteína & - & - & 0,7 & - & + \\
\hline Trealose & - & - & 1,0 & - & - \\
\hline Álcool Polivinílico & - & - & 1,0 & - & - \\
\hline Albumina Sérica & & & & & \\
\hline Bovina & - & - & - & 2,5 & + \\
\hline Tampão HEPES & - & - & - & 9,0 & - \\
\hline Tampão MOPS & & & & & + \\
\hline Água Destilada & qsp & adicionar & qsp & qsp & qsp \\
\hline & 1000 & & & & 1000 \\
\hline & $\mathrm{mL}$ & $1000 \mathrm{~mL}$ & $1000 \mathrm{~mL}$ & $1000 \mathrm{~mL}$ & $\mathrm{~mL}$ \\
\hline
\end{tabular}
al. (1994).

* QSP: Quantidade Suficiente Para $1000 \mathrm{~mL}$ 
MOUTINHO, E.P.M. et al. Efeito de diferentes antibióticos na composição do diluente, sobre a viabilidade do sêmen suíno refrigerado. PUBVET, Londrina, V. 5, N. 19, Ed. 166, Art. 1121, 2011.

\subsubsection{Componentes dos diluidores}

\subsubsection{1 Água}

A água é um componente essencial e de grande importância para a preservação do sêmen, pois mais de $80 \%$ do diluidor é composto por água, sendo a sua qualidade um fator fundamental para preservar a viabilidade das células espermáticas durante o período de estocagem, sendo os equipamentos mais utilizados para a purificação da água os deionizadores e destiladores (ERICH, 2003).

\subsubsection{Açúcares}

A fonte primária de energia nos diluidores são os açúcares, principalmente glicose, frutose e lactose. Outras fontes, como galactose, ribose e trealose também têm sido utilizadas, embora não tenham apresentado resultados melhores que a glicose (LEVIS, 2000). Os açúcares atuam também na osmolaridade e como um crioprotetor extracelular (PAQUIGNON, 1985). A degradação da glicose, pelo metabolismo espermático, tem como componentes finais dióxido de carbono $\left(\mathrm{CO}_{2}\right)$, água e produtos ácidos que alteram o ambiente em que os espermatozóides se encontram (HAMMERSTEDT, 1993).

\subsubsection{Eletrólitos}

Os eletrólitos são substâncias não metálicas que, em solução, tornam-se condutores iônicos usados para regular a pressão osmótica. Íons inorgânicos, como cloreto de potássio e cloreto de sódio, são adicionados aos diluidores para balancear a pressão osmótica (JOHNSON et al., 2000).

A osmolaridade do diluidor, mantida, principalmente, por componentes não iônicos como a glicose (JOHNSON et al., 2000), é um fator importante para evitar danos à célula espermática do ejaculado suíno (LEVIS, 2000).

O espermatozóide suíno tolera uma osmolaridade entre 240 e 380 mOsm, embora pareça que meios isotônicos ou levemente hipertônicos proporcionam melhor preservação da capacidade fecundante quando comparados aos meios com maior hipertonicidade (WEITZE, 1990a). 
MOUTINHO, E.P.M. et al. Efeito de diferentes antibióticos na composição do diluente, sobre a viabilidade do sêmen suíno refrigerado. PUBVET, Londrina, V. 5, N. 19, Ed. 166, Art. 1121, 2011.

Entretanto, uma pressão osmótica abaixo de 200 mOsm reduz significativamente a motilidade ( FRASER et al.,2001).

\subsubsection{Estabilizadores de membranas}

A célula espermática é envolta por uma membrana plasmática constituída de proteínas e lipídios, que sofre mudanças durante a espermatogênese, trânsito epididimário, ejaculação, estocagem e resfriamento (HAMMERSTEDT \& PARKS, 1987).

Vários tipos de componentes têm sido adicionados aos diluidores visando prevenir ou retardar as alterações estruturais e funcionais da membrana plasmática (LEVIS, 2000), dentre eles, a Albumina Sérica Bovina (BSA), o Butilato de Hidroxitolueno (BHT), o ácido etileno-diamino-tetracético (EDTA), o álcool polivinílico (PVP-40) e o 2-Hidroxipropil-beta-ciclodextrina (HBCD).

\subsubsection{Tampões}

A concentração de íons $\mathrm{H}^{+}$numa solução é conhecida como pH (LEVIS, 2000). O pH do sêmen a fresco do suíno é levemente alcalino, oscilando entre 7,3 a 7,9 (HAFEZ, 1993). Quando o pH é reduzido, o metabolismo e a motilidade também o são (HANCOCK E HOWELL, 1959).

O ácido lático é o principal metabólito deste processo e tem sido usado como um indicador da qualidade do sêmen, em virtude de ser oriundo do metabolismo da célula espermática bem como de bactérias. A concentração de ácido lático aumenta durante a preservação do sêmen, com o valor do $\mathrm{pH}$ tornando-se mais ácido durante o período de armazenamento (LEVIS, 2000). Desta forma, para que o $\mathrm{pH}$ do sêmen diluído mantenha-se dentro de limites aceitáveis para a adequada sobrevivência espermática, tampões têm sido incorporados aos diluidores. Os tampões comumente utilizados são o bicarbonato de sódio, o citrato de sódio e o cloreto de potássio, mas com capacidade limitada (LEVIS, 2000). Estes sais são comumente utilizados como tampões para manter a bomba de sódio e potássio da célula, prevenindo a 
MOUTINHO, E.P.M. et al. Efeito de diferentes antibióticos na composição do diluente, sobre a viabilidade do sêmen suíno refrigerado. PUBVET, Londrina, V. 5, N. 19, Ed. 166, Art. 1121, 2011.

exaustão de potássio e, consequentemente, a perda de motilidade (JONHSON et al., 2000).

\subsubsection{Antioxidantes}

A peroxidação dos lipídios ocorre nas espécies reativas ao oxigênio durante a preservação do sêmen, podendo ser agravada na presença de maior proporção de ácidos graxos insaturados e do baixo nível de antioxidante presente no espermatozóide. Assim, a suplementação com vários tipos de antioxidantes tem melhorado a viabilidade e motilidade espermáticas no sêmen diluído ou criopreservado de várias espécies (FUNAHASHI \& SANO, 2005).

O butilato de hidroxitolueno (BHT) é um antioxidante e tem solubilidade extremamen- te baixa em soluções aquosas (LEVIS, 2000).

O BHT atua na membrana plasmática aumentando a sua fluidez e tornando as células espermáticas do touro (GRAHAM \& HAMMERSTEDT, 1992), carneiro (WATSON \& ANDERSON, 1983) e varrão (BAMBA \& CRAN, 1992) menos susceptíveis ao choque térmico. Além disso, o BHT mostra-se efetivo quando as células espermáticas do varrão são submetidas ao resfriamento lento a $5^{\circ} \mathrm{C}$ (JONHSON et al., 2000).

\subsubsection{Antibióticos}

Vários agentes antimicrobianos, dentre eles gentamicina, penicilina, estreptomicina, têm sido utilizados nos diluentes comerciais para controlar ou inibir o crescimento bacteriano, uma vez que a temperatura na qual as doses inseminantes são estocadas não é capaz de impedi-lo (FERREIRA et al., 2005).

\subsection{Flora Bacteriana do Sêmen de Suíno}

Bons resultados reprodutivos estão associados à qualidade da dose inseminante, independentemente da espécie. Todos os procedimentos realizados antes da utilização do sêmen devem estar sob controle de forma a evitar as contaminações bacterianas oriundas do próprio animal (processos 
MOUTINHO, E.P.M. et al. Efeito de diferentes antibióticos na composição do diluente, sobre a viabilidade do sêmen suíno refrigerado. PUBVET, Londrina, V. 5, N. 19, Ed. 166, Art. 1121, 2011.

infecciosos), da falta de higiene, da técnica de coleta utilizada ou da manipulação durante o processamento ou transporte da dose inseminante (ALMOND \& POOLPERM, 1996).

As diferenças encontradas quanto ao aspecto microbiológico do sêmen se devem aos métodos utilizados para avaliar o crescimento bacteriano, o método de coleta ou a forma de higienização durante a mesma, além das diferenças entre indivíduos (AAMDAL et al., 1958). Práticas apropriadas de higienização antes e durante a coleta, e eliminação das frações pré-espermática e gel têm sido as medidas mais eficazes para reduzir a contaminação do ejaculado e o crescimento bacteriano do sêmen suíno armazenado (AAMDAL et al, 1958; ALTHOUSE \& LU, 2005).

A fonte primária de contaminação bacteriana é o próprio varrão. Outros fatores podem potencializar o crescimento bacteriano no sêmen, como as fezes e o fluido do divertículo prepucial. A contaminação pode originar-se de uma única fonte, como por exemplo, a mão do coletador, materiais usados no laboratório (pipetas e termômetros) e a água usada no preparo do diluidor, principalmente nos períodos chuvosos (ALTHOUSE et al., 2000). Alguns equipamentos, como banho-maria e estufa, uma vez contaminados, produzem excelente ambiente para o crescimento bacteriano, tornando-se fontes de contaminação para outros equipamentos e para o próprio sêmen (ALMOND \& POOLPERM, 1996). As bactérias sobrevivem muito bem nos diluidores normalmente utilizados, quando antibióticos não são adicionados a eles. O diluidor BTS, por exemplo, têm em sua composição 37 gramas de glicose por litro, sendo que, para o crescimento de E. coli, são necessários apenas dois gramas de glicose por litro (ALMOND \& POOLPERM, 1996).

A Tabela 2 mostra alguns dos principais microrganismos isolados de sêmen in natura e diluído em cinco centrais de IA de suínos (BENNEMAN, 1998). 
MOUTINHO, E.P.M. et al. Efeito de diferentes antibióticos na composição do diluente, sobre a viabilidade do sêmen suíno refrigerado. PUBVET, Londrina, V. 5, N. 19, Ed. 166, Art. 1121, 2011.

TABELA 2 - Bactérias mais prevalentes, isoladas do sêmen in natura e diluído em cinco centrais de inseminação artificial de suínos.

\begin{tabular}{llllll}
\multicolumn{1}{c}{ Bactérias/Centrais } & $\mathrm{A}$ & $\mathrm{B}$ & $\mathrm{C}$ & $\mathrm{D}$ & $\mathrm{E}$ \\
Staphylococcus sp. & $*$ & $*$ & $*$ & $*$ & $*$ \\
Estreptococcus sp. & $*$ & $*$ & $*$ & $*$ & $*$ \\
Escherichia coli & & & $*$ & & $*$ \\
Pseudomonas sp. & $*$ & $*$ & & $*$ & \\
Bacillus sp. & $*$ & & & & \\
\hline
\end{tabular}

Fonte: Bennemann (1998).

O efeito deletério da contaminação bacteriana pode ser produzido direta ou indiretamente pelas bactérias nos espermatozóides. No decorrer do período de armazenamento, o aumento da população microbiana pode levar ao acúmulo de toxinas e metabólitos que afetam a sobrevivência e a capacidade fecundante dos espermatozóides. Além disso, a acidificação do meio causado pela maioria das bactérias, exceto Escherichia coli, poderá levar à redução da viabilidade espermática causando assim um efeito espermicida diretamente sobre a célula (ALTHOUSE et al., 2000).

\subsection{Antibióticos Utilizados no Sêmen de Varrões}

Os antibióticos têm sido utilizados no sêmen diluído por mais de 40 anos, embora tenham apresentado efeitos benéficos e prejudiciais (POOLPERM, 2001).

Segundo Sone (1982), os antibióticos são utilizados para prevenir a contaminação do trato genital da fêmea suína e evitar que a qualidade do sêmen e longevidade sejam prejudicadas, onde a associação de antibióticos mais comum é a da penicilina com a estreptomicina. A escolha da estreptomicina tem se mostrado em ser utilizada na presença de leptospirose em várias regiões (VAN SCHIE, 1996).

A seleção apropriada do antibiótico requer algumas considerações e tem sido um problema de difícil solução. Considerando que as bactérias podem desenvolver resistência aos antibióticos quando usados por muito tempo ou 
MOUTINHO, E.P.M. et al. Efeito de diferentes antibióticos na composição do diluente, sobre a viabilidade do sêmen suíno refrigerado. PUBVET, Londrina, V. 5, N. 19, Ed. 166, Art. 1121, 2011.

continuamente em doses baixas (ALMOND \& POOLPERM, 1996), outros grupos de antibióticos, como os aminoglicosídeos e combinações entre eles têm sido estudados (WALTZ et al.,1968) ou, ainda, diferentes temperaturas de armazenamento (POOLPERM, 2001). Os aminoglicosídeos como sulfato de gentamicina, vanamicina, neomicina e polimixina B também têm sido usados nos diluidores (ALTHOUSE et al., 2000).

Segundo Sone (1982), os aminoglicosídeos são considerados como os antibióticos mais efetivos para controlar a contaminação de $E$. coli no sêmen.

Deve-se considerar que durante o tratamento de infecções bacterianas, são necessárias várias doses de antibióticos para manter a concentração mínima inibitória adequada nos tecidos ou no sangue (ALMOND \& POOLPERM, 1996).

A escolha do antibiótico não garante a total proteção espermática contra seus efeitos deletérios. Além disso, observa-se que a resistência aos antibióticos freqüentemente usados nos diluidores é comum (ALTHOUSE \& LU, 2005).

O controle do crescimento bacteriano tem sido relacionado como um dos principais problemas envolvendo a utilização da IA em suínos. A coleta de um ejaculado livre de contaminação na rotina das centrais é praticamente impossível e, na temperatura de armazenamento do sêmen, geralmente entre $15^{\circ} \mathrm{C}$ e $2^{\circ} \mathrm{C}$, não ocorre inibição do crescimento bacteriano (WALTZ et al.,1968), como é o caso das bactérias gram negativas E.coli, Salmonella e Pseudomonas, que sobrevivem e crescem nesta faixa de temperatura (ALMOND \& POOLPERM, 1996).

O crescimento bacteriano, por sua vez, pode prejudicar a qualidade do sêmen bem como a sua longevidade, devido à redução da motilidade, presença de aglutinação ou "clumping" (aglomerado de células com dificuldade de se dispersar e que apresentam movimento estático), anormalidades de acrossomas e redução do pH (ALTHOUSE et al., 2000).

Assim, além da adição obrigatória de antibióticos aos diluidores de sêmen, medidas preventivas rigorosas devem ser tomadas para a redução da 
MOUTINHO, E.P.M. et al. Efeito de diferentes antibióticos na composição do diluente, sobre a viabilidade do sêmen suíno refrigerado. PUBVET, Londrina, V. 5, N. 19, Ed. 166, Art. 1121, 2011.

contaminação das doses inseminantes, desde a preparação do varrão para a coleta até o processamento do sêmen. É recomendável que se realize avaliações de amostras de sêmen para o melhor controle bacteriano das amostras com 48 horas pós-processamento (ALTHOUSE \& LU, 2005).

\section{MATERIAL E MÉTODOS}

\subsection{Experimento 1: - Avaliação da Viabilidade Espermática}

O experimento foi conduzido na estação experimental de Zootecnia do Instituto Federal Goiano - Campus Rio Verde no período de 06/07/2009 à $27 / 07 / 2009$. Os machos utilizados foram selecionados aleatoriamente de uma leitegada recém desmamada em função do desempenho dos mesmos. Os animais foram mantidos em baias coletivas até a puberdade, sendo então, transferidos aos sete meses de idade para gaiolas individuais, iniciando-se então o processo de treinamento dos animais para saltarem sob o manequim, para então serem realizadas as colheitas de sêmen.

Diariamente a partir da puberdade, os animais eram alimentados com dois $\mathrm{Kg}$ de ração (em dois arraçoamentos), e água ad libitum. O manejo de condicionamento e treinamento dos animais até o manequim foi realizado inicialmente três vezes por semana durante um período de 15 minutos. Com os animais já adaptados, manteve-se o ritmo de uma colheita de sêmen semanal.

O manequim para colheita fixado na parte central da sala era protegido por uma manta de borracha para melhor conforto dos animais durante os saltos a fim de evitar incisões nas regiões do abdômen e prepúcio. Os materiais empregados nas colheitas foram luvas, papel toalha e copo coletor.

Precedente aos saltos realizava-se uma higienização da região prepucial dos animais para evitar a contaminação do ejaculado.

As colheitas foram realizadas através da técnica da mão enluvada após a exteriorização e direcionamento do pênis, em recipiente plástico de $500 \mathrm{~mL}$ previamente aquecido em estufa à temperatura de $35^{\circ} \mathrm{C}-37^{\circ} \mathrm{C}$, tendo sobre a 
MOUTINHO, E.P.M. et al. Efeito de diferentes antibióticos na composição do diluente, sobre a viabilidade do sêmen suíno refrigerado. PUBVET, Londrina, V. 5, N. 19, Ed. 166, Art. 1121, 2011.

cobertura, papel filtro para retenção da fração gelatinosa. Quatro reprodutores suínos, foram utilizados, totalizando seis ejaculados por animal, para refrigeração das alíquotas de sêmen em três tratamentos.

O meio utilizado para diluição das amostras foi preparado com $12,5 \mathrm{~g}$ de Proli-Max ${ }^{\circledR}$ (Vet Life - Nova Odessa - SP ) e $250 \mathrm{~mL}$ de água destilada. Para cada antibiótico usado, considerava-se a mesma quantidade de diluente preparado (12,5 g de Proli-Max ${ }^{\circledR} / 250 \mathrm{~mL}$ de água destilada), onde se tinha variação apenas na quantidade de cada antibiótico utilizado.

Após a colheita de sêmen, realizava-se a filtração no laboratório, para retirada da porção gel sendo então avaliados em seguida o volume, motilidade total, motilidade progressiva, vigor, e concentração do sêmen puro para verificar sua qualidade, para ser então refrigerado. Em seguida, dividiu-se o sêmen em três partes para diluição de acordo com os seguintes tratamentos:

Tratamento I - sêmen diluído para uma concentração de $50 \times 10^{6}$ espermatozóides por $\mathrm{mL}$, com Proli-Max ${ }^{\circledR}$ (Vet Life, Nova Odessa - SP) contendo o antibiótico Excenel ${ }^{\circledR}$ (Pfizer - Guarulhos - SP ) - 0,33 mL/250 mL de Proli-Max ${ }^{\circledR}$ diluído (Cloridato de Ceftiofur - 66,6 mg/L);

Tratamento II - sêmen diluído com Proli-Max ${ }^{\circledR}$ contendo o antibiótico Estreptomicina $5 g^{\circledR}$ (Vitalfarma - São Sebastião do Paraíso - MG) - 0,25g/250 $\mathrm{mL}$ de Proli-Max ${ }^{\circledR}$ diluído (Sulfato de Estreptomicina - 1,0 g/L);

Tratamento III - sêmen diluído com Proli-Max ${ }^{\circledR}$ contendo o antibiótico Gentaflex ${ }^{\circledR}$ (Eurofarma - São Paulo - SP) - 1,9 mL/250 mL de Proli-Max ${ }^{\circledR}$ diluído (Sulfato de Gentamicina - 300 mg/L).

Logo após a diluição do sêmen, no momento (T0), foram avaliados os parâmetros de qualidade do sêmen dilúido: motilidade total (MT - \%), motilidade progressiva (MP - \%) e vigor ( $\mathrm{V}$ - 0 a 5 ).

As amostras de sêmen diluído foram acondicionadas em tubos de centrífuga de $15 \mathrm{~mL}$ e refrigeradas a $17^{\circ} \mathrm{C}$. As avaliações foram novamente realizadas após 24 (T24), 48 (T48), e 72 (T72) horas de refrigeração. 
MOUTINHO, E.P.M. et al. Efeito de diferentes antibióticos na composição do diluente, sobre a viabilidade do sêmen suíno refrigerado. PUBVET, Londrina, V. 5, N. 19, Ed. 166, Art. 1121, 2011.

As análises de MT (\%), MP (\%) e vigor (0-5) foram realizadas através de microscopia óptica, utilizando uma gota de sêmen colocada entre lâmina e lamínula, previamente aquecidas a $37^{\circ} \mathrm{C}$.

Para as análises nos momentos T24, T48 e T72 horas, retirava-se um mL de cada amostra que eram colocados em eppendorfs previamente identificados com os antibióticos testados, sendo estas amostras pré-aquecidas por 10 minutos a $37^{\circ} \mathrm{C}$.

Para análise estatística utilizou-se um esquema fatorial $3 \times 4$ (três antibióticos $x$ quatro tempos), com avaliação de análise de variância comparada entre as médias dos grupos seguido do teste de Tukey. O nível de significância considerado foi de $5 \%$ sendo o programa utilizado para as análises estatísticas o software Sisvar 5.0 versão - 2009.

\subsection{Experimento 2: - Avaliação do Crescimento Bacteriano}

Para avaliação da eficiência dos antibióticos testados no controle do crescimento bacteriano, no sêmen refrigerado de varrões, realizaram-se cinco colheitas de sêmen de um varrão, conforme metodologia descrita no experimento 1 .

Após a colheita o ejaculado foi filtrado, analisado e em seguida diluído de acordo com os seguintes grupos:

Grupo I - sêmen diluído com Proli-Max ${ }^{\circledR}$ Vet Life $(12,5 \mathrm{~g}$ em $250 \mathrm{~mL}$ de água destilada); sem Antibiótico (Controle).

Grupo II - sêmen diluído com Proli-Max ${ }^{\circledR}$ Vet Life $(12,5 \mathrm{~g}$ em $250 \mathrm{~mL}$ de água destilada) contendo o antibiótico Cloridato de Ceftiofur $(66,6 \mathrm{mg} / \mathrm{L})$ - Excenel $^{\circledR}$ $0,33 \mathrm{~mL} / 250 \mathrm{~mL}$ de Proli-Max ${ }^{\circledR}$ diluído;

Grupo III - sêmen diluído com Proli-Max ${ }^{\circledR}$ Vet Life $(12,5 \mathrm{~g}$ em $250 \mathrm{~mL}$ de água destilada) contendo o antibiótico Sulfato de Estreptomicina (1,0 g/L) Estreptomicina $5 \mathrm{~g}^{\circledR} 0,25 \mathrm{~g} / 250 \mathrm{~mL}$ de Proli-Max ${ }^{\circledR}$ diluído;

Grupo IV - sêmen diluído com Proli-Max ${ }^{\circledR}$ Vet Life $(12,5 \mathrm{~g}$ em $250 \mathrm{~mL}$ de água destilada) contendo o antibiótico Sulfato de Gentamicina (300 mg/L) Gentaflex ${ }^{\circledR} 1,9 \mathrm{~mL} / 250 \mathrm{~mL}$ de Proli-Max ${ }^{\circledR}$ diluído. 
MOUTINHO, E.P.M. et al. Efeito de diferentes antibióticos na composição do diluente, sobre a viabilidade do sêmen suíno refrigerado. PUBVET, Londrina, V. 5, N. 19, Ed. 166, Art. 1121, 2011.

As amostras de sêmen foram conservadas sob refrigeração à $17^{\circ} \mathrm{C}$ por 72 horas. Foi avaliado crescimento bacteriano das amostras oriundas de um mesmo varrão logo após a diluição (T0), após 24 (T24), 48 (T48) e 72 (T72) horas de refrigeração.

Em cada momento avaliado, realizou-se uma diluição retirando-se um $\mathrm{mL}$ de cada amostra que foi adicionada a tubos de ensaio contendo $9 \mathrm{~mL}$ de solução salina, constituindo-se um fator de diluição $10^{-1}$ e desta solução, 100 microlitros ou $0,1 \mathrm{~mL}$ foram inoculados em placas de Petri esterilizadas e devidamente identificadas com 0 respectivo tratamento e tempo de refrigeração contendo meio de cultivo enriquecido BHI (Infusão de Cérebro e Coração) recomendado para o cultivo de bactérias exigentes, sendo este procedimento repetido em todos os grupos.

Realizaram-se movimentos circulares nas placas pela técnica de espalhamento por superfície utilizando-se uma alça de Drigaslky, com o intuito de se obter uma boa homogeinização do inóculo sobre a superfície do ágar.

Após a semeadura, as placas foram incubadas a $37^{\circ} \mathrm{C}$, por 48 horas, para verificar o crescimento bacteriano.

Após as placas permanecerem por 48 horas na estufa, realizou-se então a contagem das colônias de bactérias de forma direta sobre as placas. Estabeleceu-se uma contagem entre 30 a 300 colônias para quantificação das mesmas. Os resultados da contagem foram expressos em Unidade Formadora de Colônia (UFC) ou número de colônias por $\mathrm{mL}$. Para as análises estatísticas os dados foram transformados para logarítmo. O delineamento experimental utilizado foi o de esquema em fatorial $4 \times 4$ (quatro antibióticos $x$ quatro tempos) com análise estatística feita pela avaliação das médias seguida do teste de Tukey para a comparação entre os grupos. A análise das diferenças entre as médias foi feita utilizando o programa Sisvar 5.0 versão - 2009, com um intervalo de confiança de $5 \%(p<0,05)$. 
MOUTINHO, E.P.M. et al. Efeito de diferentes antibióticos na composição do diluente, sobre a viabilidade do sêmen suíno refrigerado. PUBVET, Londrina, V. 5, N. 19, Ed. 166, Art. 1121, 2011.

\section{RESULTADOS E DISCUSSÃo}

\subsection{Experimento 1: Avaliação da Viabilidade Espermática}

Os dados apresentados nas Tabelas 3, 4, 5 e 6 mostram as médias de MT (\%), MP (\%) e V (0-5) dos tratamentos avaliados nos momentos T0, T24, T48 e T72, respectivamente.

Não foi observada diferença significativa entre os tratamentos utilizados, logo após a diluição conforme o demonstrado na tabela três. Entretanto, houve influência dos tratamentos testados sobre a viabilidade espermática após as amostras terem sido refrigeradas por 24 horas, de acordo com os resultados apresentados na tabela quatro.

Após 48 e 72 horas de refrigeração, observou-se uma redução nas taxas de motilidade total, progressiva e vigor, na presença da gentamicina sobre os outros antibióticos na qualidade do sêmen, conforme as tabelas cinco e seis, mostrando-se o antibiótico de menor potencialidade para manutenção da qualidade do sêmen suíno refrigerado.

TABELA 3 - Porcentagem de MT, MP e Vigor do sêmen de reprodutores suínos no momento T0, logo após a diluição.

\begin{tabular}{lccc}
\hline & \multicolumn{3}{c}{ Parâmetros } \\
\cline { 2 - 4 } Tratamentos & MT (\%) & MP (\%) & V (0-5) \\
\hline C. Ceftiofur & $78,54 \mathrm{a}$ & $71,25 \mathrm{a}$ & $2,79 \mathrm{a}$ \\
S. Estreptomicina & $78,33 \mathrm{a}$ & $69,12 \mathrm{a}$ & $2,75 \mathrm{a}$ \\
S. Gentamicina & $73,54 \mathrm{a}$ & $66,45 \mathrm{a}$ & $2,66 \mathrm{a}$ \\
\hline * C.V. (\%) & 22,49 & 28,07 & 24,22
\end{tabular}

*Médias seguidas de letras diferentes nas colunas diferem significativamente pelo teste de Tukey $(\mathrm{P}<0,05)$.

*C.V.: Coeficiente de Variação 
MOUTINHO, E.P.M. et al. Efeito de diferentes antibióticos na composição do diluente, sobre a viabilidade do sêmen suíno refrigerado. PUBVET, Londrina, V. 5, N. 19, Ed. 166, Art. 1121, 2011.

TABELA 4 - Porcentagem de MT, MP e Vigor do sêmen de reprodutores suínos com 24 horas de refrigeração.

\begin{tabular}{lccc}
\hline & \multicolumn{3}{c}{ Parâmetros } \\
\cline { 2 - 4 } Tratamentos & MT (\%) & MP (\%) & V (0-5) \\
\hline C. Ceftiofur & $52,29 \mathrm{ab}$ & $42,29 \mathrm{a}$ & $1,87 \mathrm{a}$ \\
S. Estreptomicina & $63,95 \mathrm{a}$ & $50,00 \mathrm{a}$ & $2,20 \mathrm{a}$ \\
S. Gentamicina & $47,29 \mathrm{~b}$ & $36,91 \mathrm{a}$ & $1,70 \mathrm{a}$ \\
\hline C.V. (\%) & 22,49 & 28,07 & 24,22 \\
\hline
\end{tabular}

* Médias seguidas de letras diferentes nas colunas diferem significativamente pelo teste de Tukey $(P<0,05)$.

*C.V.: Coeficiente de Variação

TABELA 5 - Porcentagem de MT, MP e Vigor do sêmen de reprodutores suínos com 48 horas de refrigeração.

\begin{tabular}{lccc}
\hline & \multicolumn{3}{c}{ Parâmetros } \\
\cline { 2 - 4 } Tratamentos & MT (\%) & MP (\%) & V (0-5) \\
\hline C. Ceftiofur & $48,33 \mathrm{a}$ & $36,16 \mathrm{a}$ & $1,70 \mathrm{a}$ \\
S. Estreptomicina & $57,70 \mathrm{a}$ & $45,62 \mathrm{a}$ & $1,79 \mathrm{a}$ \\
S. Gentamicina & $23,54 \mathrm{~b}$ & $12,70 \mathrm{~b}$ & $0,83 \mathrm{~b}$ \\
\hline C.V. $(\%)$ & 22,49 & 28,07 & 24,22
\end{tabular}

*Médias seguidas de letras diferentes nas colunas diferem significativamente pelo teste de Tukey $(\mathrm{P}<0,05)$.

*C.V.: Coeficiente de Variação

Os resultados deste trabalho diferem dos encontrados por Martin-Rillo et al. (1984), que citam a gentamicina como um antimicrobiano adequado às condições de conservação prolongada dos espermatozóides do varrão. Entretanto, os resultados observados neste trabalho assemelham-se aos encontrados por Reis et al. (1999); Gopalkrishnan et al. (1994) e Kemp \& Soede (1997) que afirmaram que a gentamicina apresenta efeito negativo sobre a motilidade espermática apesar de não apresentar efeito deletério sobre a integridade do acrossoma. 
MOUTINHO, E.P.M. et al. Efeito de diferentes antibióticos na composição do diluente, sobre a viabilidade do sêmen suíno refrigerado. PUBVET, Londrina, V. 5, N. 19, Ed. 166, Art. 1121, 2011.

TABELA 6 - Porcentagem de MT, MP e Vigor do sêmen de reprodutores suínos com 72 horas de refrigeração.

\begin{tabular}{lccc}
\hline & \multicolumn{3}{c}{ Parâmetros } \\
\cline { 2 - 4 } Tratamentos & MT (\%) & MP (\%) & V (0-5) \\
\hline C. Ceftiofur & $41,25 \mathrm{a}$ & $32,70 \mathrm{a}$ & $1,20 \mathrm{a}$ \\
S. Estreptomicina & $56,66 \mathrm{a}$ & $46,04 \mathrm{a}$ & $1,58 \mathrm{a}$ \\
S. Gentamicina & $4,37 \mathrm{~b}$ & $1,87 \mathrm{~b}$ & $0,29 \mathrm{~b}$ \\
\hline C.V. $(\%)$ & 22,49 & 28,07 & 24,22 \\
\hline Médias seguidas de letras diferentes nas colunas diferem significativamente pelo teste de \\
ukey $(\mathrm{P}<0,05)$. *C.V.: Coeficiente de Variação
\end{tabular}

Desta forma, o uso deste antibiótico no meio diluidor do sêmen suíno deve ser melhor avaliado.

A membrana plasmática do espermatozóide de reprodutores suínos mostra-se altamente sensível a temperaturas de armazenamento abaixo de 10 ${ }^{\circ} \mathrm{C}$ de refrigeração e principalmente congelação devido a mesma possuir pouca quantidade de colesterol na sua constituição estrutural (DE LEEUW et al., 1990). Sendo assim, antibióticos mais oleosos como o Excenel ${ }^{\circledR}$ (Cloridrato de ceftiofur), podem proporcionar aos espermatozóides maior proteção contra o efeito da temperatura sobre a qualidade dos parâmetros espermáticos, podendo agir como um bom crioprotetor.

O efeito crioprotetor do colesterol parece ser importante durante a fase de transição, na qual os lipídios da membrana passam de um estado líquido cristalino para o estado gel durante o resfriamento (PURDY \& GRAHAM, 2004b). Avaliando o efeito da incorporação do colesterol à membrana plasmática de espermatozóides eqüinos, ZAHN (2002), cita que a incorporação do colesterol não interfere no vigor, nem na motilidade subjetiva dos espermatozóides. Sêmen bovino com a adição de colesterol, resulta em altos percentuais de motilidade e viabilidade espermática após a descongelação (AMORIM et al, 2009; PURDY \& GRAHAM, 2004b). Segundo Zahn (2002), a adição do colesterol aumenta a relação colesterol: fosfolipídio, elevando a 
MOUTINHO, E.P.M. et al. Efeito de diferentes antibióticos na composição do diluente, sobre a viabilidade do sêmen suíno refrigerado. PUBVET, Londrina, V. 5, N. 19, Ed. 166, Art. 1121, 2011.

rigidez da membrana, o que compromete a capacitação e a reação do acrossomo essenciais para que a fertilização do oócito ocorra (ZAHN, 2002).

Estudos mostram que a adição de colesterol à membrana impede que ocorra a perda deste durante os processos de criopreservação (MOORE et al., 2005). Porém, o excesso de colesterol pode afetar a ocorrência da capacitação e da reação do acrossomo (ZAHN, 2002; PURDY \& GRAHAM, 2004b). A diferença na composição da membrana espermática entre indivíduos de espécies diferentes e dentro da mesma espécie faz com que um determinado diluidor possa conferir maior ou menor proteção aos espermatozóides (OLIVEIRA, 2003).

O grupo Gentamicina demonstrou uma tendência em reduzir o potencial fertilizante do sêmen refrigerado de suínos.

Os dados apresentados nas tabelas 7, 8 e 9 mostram respectivamente as médias de MT (\%), MP (\%), e V (0-5) dentro dos tratamentos avaliados nos momentos 0, 24, 48 e 72 horas de refrigeração.

Em decorrência dos resultados, nota-se influência de interação entre o tempo de refrigeração e tratamentos utilizados sobre a manutenção da qualidade do sêmen.

A MT do sêmen diluído com Cloridrato de Ceftiofur reduziu do momento 0 hora para o 24 horas, $(p<0,05)$. Porém, a MT das amostras se manteve semelhante de 24 até 72 horas, $(p>0,05)$. Resultado semelhante foi observado com o antibiótico Sulfato de Estreptomicina. Entretanto, as amostras diluídas com o antibiótico Sulfato de Gentamicina apresentaram uma redução da MT com o passar do tempo $(p<0,05)$, conforme os resultados demonstrados na Tabela 7.

Os resultados de MP das amostras, dentro de cada grupo entre os tempos de refrigeração foram semelhantes aos resultados da MT, pois tanto utilizando Cloridrato de Ceftiofur quanto Sulfato de Estreptomicina as motilidades progressivas do momento 24 horas foram iguais as dos momentos 48 e 72 horas. Entretanto, a motilidade progressiva do grupo Sulfato de 
MOUTINHO, E.P.M. et al. Efeito de diferentes antibióticos na composição do diluente, sobre a viabilidade do sêmen suíno refrigerado. PUBVET, Londrina, V. 5, N. 19, Ed. 166, Art. 1121, 2011.

Gentamicina reduziu com o passar do tempo, conforme os dados apresentados na Tabela oito.

TABELA 7 - Porcentagem de MT do sêmen de reprodutor suíno diluído com os antibióticos Cloridrato de Ceftiofur, Sulfato de Estreptomicina e Sulfato de Gentamicina nos momentos 0, 24, 48 e 72 horas de refrigeração.

\begin{tabular}{cccc}
\hline & \multicolumn{3}{c}{ Antibióticos } \\
\hline Tempo & C. Ceftiofur & S. Estreptomicina & S. Gentamicina \\
0 & $78,54 \mathrm{Aa}$ & $78,33 \mathrm{Aa}$ & $73,54 \mathrm{Aa}$ \\
24 & $52,29 \mathrm{ABb}$ & $63,95 \mathrm{Aab}$ & $47,29 \mathrm{Bb}$ \\
48 & $48,33 \mathrm{Ab}$ & $57,70 \mathrm{Ab}$ & $23,54 \mathrm{Bc}$ \\
72 & $41,25 \mathrm{Ab}$ & $56,66 \mathrm{Ab}$ & $4,37 \mathrm{Bd}$ \\
\hline Fontes de Variação & - & - & - \\
\hline Antibiótico & 0,0000 & - & - \\
Tempo & 0,0000 & - & - \\
Antibiótico x Tempo & 0,0002 & - & - \\
\hline *C.V. (\%) & 22,49 & - & - \\
\hline
\end{tabular}

*Médias seguidas de letras diferentes, maiúsculas nas linhas e minúsculas nas colunas diferem significativamente pelo teste de Tukey $(P<0,05)$.

*C.V.: Coeficiente de variação

TABELA 8 - Porcentagem de MP do sêmen de reprodutor suíno diluído com os antibióticos Cloridrato de Ceftiofur, Sulfato de Estreptomicina e Sulfato de Gentamicina nos momentos 0, 24, 48 e 72 horas de refrigeração.

\begin{tabular}{cccc}
\hline & \multicolumn{3}{c}{ Antibióticos } \\
\hline Tempo & C. Ceftiofur & S. Estreptomicina & S. Gentamicina \\
0 & $71,25 \mathrm{Aa}$ & $69,12 \mathrm{Aa}$ & $66,45 \mathrm{Aa}$ \\
24 & $42,29 \mathrm{Ab}$ & $50,00 \mathrm{Ab}$ & $36,91 \mathrm{Ab}$ \\
48 & $36,16 \mathrm{Ab}$ & $45,62 \mathrm{Ab}$ & $12,70 \mathrm{Bc}$ \\
72 & $32,70 \mathrm{Ab}$ & $46,04 \mathrm{Ab}$ & $1,87 \mathrm{Bc}$ \\
\hline Fontes de Variação & - & - & - \\
\hline Antibiótico & 0,0000 & - & - \\
Tempo & 0,0000 & - & - \\
Antibiótico x Tempo & 0,0021 & - & - \\
\hline *C.V. $(\%)$ & 28,07 & - & -
\end{tabular}

*Médias seguidas de letras diferentes, maiúsculas nas linhas e minúsculas nas colunas diferem significativamente pelo teste de Tukey $(P<0,05)$. *C.V.: Coeficiente de variação 
MOUTINHO, E.P.M. et al. Efeito de diferentes antibióticos na composição do diluente, sobre a viabilidade do sêmen suíno refrigerado. PUBVET, Londrina, V. 5, N. 19, Ed. 166, Art. 1121, 2011.

De acordo com a tabela nove, o antibiótico Sulfato de Estreptomicina mostrou-se mais eficiente para manutenção do vigor com o passar do tempo de refrigeração, pois o vigor do sêmen manteve-se igual de 24 até 72 horas $(p>0,05)$. Entretanto, este fato não foi observado com os antibióticos Cloridrato de Ceftiofur e Sulfato de Gentamicina $(p<0,05)$.

TABELA 9 - Porcentagem de Vigor do sêmen de reprodutor suíno diluído com os antibióticos Cloridrato de Ceftiofur, Sulfato de Estreptomicina e Sulfato de Gentamicina nos momentos 0, 24, 48 e 72 horas de refrigeração.

\begin{tabular}{cccc}
\hline & \multicolumn{3}{c}{ Antibióticos } \\
\hline Tempo & C. Ceftiofur & S. Estreptomicina & S. Gentamicina \\
0 & $2,79 \mathrm{Aa}$ & $2,75 \mathrm{Aa}$ & $2,66 \mathrm{Aa}$ \\
24 & $1,87 \mathrm{Ab}$ & $2,20 \mathrm{Aab}$ & $1,70 \mathrm{Ab}$ \\
48 & $1,70 \mathrm{Abc}$ & $1,79 \mathrm{Ab}$ & $0,83 \mathrm{Bc}$ \\
72 & $1,20 \mathrm{Ac}$ & $1,58 \mathrm{Ab}$ & $0,29 \mathrm{Bc}$ \\
\hline Fontes de Variação & - & - & - \\
\hline Antibiótico & 0,0000 & - & - \\
Tempo & 0,0000 & - & - \\
Antibiótico x Tempo & 0,0213 & - & - \\
\hline C.V. $\%$ (\%) & 24,22 & - & -
\end{tabular}

*Médias seguidas de letras diferentes, maiúsculas nas linhas e minúsculas nas colunas diferem significativamente pelo teste de Tukey $(P<0,05) .{ }^{*} C . V$.: Coeficiente de variação

\subsection{Experimento 2: - Avaliação Do Crescimento Bacteriano}

A Tabela 10 demonstra as médias de unidades formadoras de colônia (UFC), obtidas através da análise microbiológica das amostras refrigeradas do sêmen de varrão.

Na Tabela 10 foi possível observar que o antibiótico Sulfato de Gentamicina, mostrou ser o mais adequado $(p<0,05)$ o controle do desenvolvimento bacteriano no sêmen diluído de reprodutores suínos. Este melhor controle do desenvolvimento bacteriano pela gentamicina poderá prolongar o período de conservação do sêmen, uma vez que haverá uma menor competição pelo oxigênio presente no meio diluidor (REIS et al., 1999). 
MOUTINHO, E.P.M. et al. Efeito de diferentes antibióticos na composição do diluente, sobre a viabilidade do sêmen suíno refrigerado. PUBVET, Londrina, V. 5, N. 19, Ed. 166, Art. 1121, 2011.

Os demais grupos não tiveram a mesma eficiência de impedir o avanço do desenvolvimento bacteriano após a refrigeração do sêmen, no entanto a Estreptomicina e Ceftiofur foram mais eficientes na auxílio da manutenção da sobrevivência espermática durante o armazenamento a $17^{\circ} \mathrm{C}$, conforme os resultados demonstrados nas Tabelas do experimento 1 , fato este que não foi observado com as amostras diluídas com Sulfato de Gentamicina.

TABELA 10 - Média de UFC/mL observadas no sêmen de reprodutor suíno, refrigerado por 24, 48 e 72 horas, diluído com os antibióticos Cloridrato de Ceftiofur, Sulfato de Estreptomicina e sulfato de Gentamicina.

\begin{tabular}{lccccc}
\hline Tratamentos & T0 & T24 & T48 & T72 & $\begin{array}{c}\text { Médias } \\
\text { UFC/ml } \\
\text { (log) }\end{array}$ \\
Sem antibiótico & 3,82 & 3,32 & 3,41 & 3,35 & $3,48 \mathrm{a}$ \\
C. Ceftiofur & 3,50 & 2,47 & 2,75 & 3,05 & $2,86 \mathrm{ab}$ \\
S. Estreptomicina & 2,33 & 2,01 & 2,68 & 2,71 & $2,55 \mathrm{Vab}$ \\
S. Gentamicina & 1,35 & 1,59 & 1,91 & 2,27 & $1,78 \mathrm{~b}$ \\
Médias & $2,75 \mathrm{a}$ & $2,35 \mathrm{a}$ & $2,69 \mathrm{a}$ & $2,85 \mathrm{a}$ & - \\
\hline CV\% & 44,06 & - & - & - & - \\
\hline Antibiótico & 0,0018 & - & - & - & - \\
Tempo & 0,6487 & - & - & - & - \\
Antib x tempo & 0,9197 & - & - & - & - \\
\hline OSdas
\end{tabular}

Os dados obtidos em UFC/mL foram transformados para logaritmo na base dez para análise estatística. *Médias seguidas de letras diferentes na coluna diferem significativamente pelo teste de Tukey $(P<0,05)$.

Embora a Gentamicina tenha se mostrado eficiente para o controle do crescimento microbiano, fato este já demonstrado por Bortolozzo et al. (2000), Reis et al., (1999), afirmaram que a gentamicina tem efeito negativo sobre a motilidade espermática apesar de não apresentar efeito deletério sobre a integridade do acrossoma. Coelho, (1976) observou que a Gentamicina é uma boa alternativa para controlar o crescimento bacteriano no processamento de doses de sêmen na concentração de $13,3 \mathrm{mg} / \mathrm{L}$. 
MOUTINHO, E.P.M. et al. Efeito de diferentes antibióticos na composição do diluente, sobre a viabilidade do sêmen suíno refrigerado. PUBVET, Londrina, V. 5, N. 19, Ed. 166, Art. 1121, 2011.

Os resultados deste trabalho foram semelhantes aos encontrados por Souza et al., (2006) que citam a Gentamicina como uma alternativa para o controle efetivo de microrganismos com a capacidade de reduzir os níveis de contaminação. Este anti-microbiano deve ser utilizado em diferentes concentrações, em virtude da possível ação tóxica que este poderá proporcionar aos espermatozóides.

No presente estudo observou-se uma eficiente ação da Gentamicina no controle do crescimento microbiano e a mesma mostrou-se ineficiente para manutenção da viabilidade espermática, talvez este fato seja conseqüência da alta concentração de Gentamicina na diluição das amostras, pois de acordo com Souza et al., (2006) este antibiótico pode ser tóxico aos espermatozóides. Mais estudos utilizando menores concentrações de Gentamicina na diluição do sêmen devem ser desenvolvidos, a fim de encontrar uma concentração ideal, a qual seja eficiente para o controle do crescimento microbiano e para manutenção da viabilidade espermática.

Desta forma, o uso de antibiótico no meio diluidor do sêmen suíno deve ser melhor avaliado em função da escassez de literatura relacionada à diferentes tipos de antimicrobianos utilizados no sêmen de reprodutores suínos (THIBIER \& GUERIN, 2000).

A associação de antibióticos, em menores concentrações pode ser eficiente, pois reduzirá o efeito tóxico de cada antibiótico mantendo a viabilidade espermática. A associação destes poderá ser eficiente para impedir o crescimento microbiano.

A relevância de se diminuir a contaminação bacteriana com o uso de antimicrobianos é proporcionar a redução de problemas referentes à aglutinação espermática, retorno ao cio e porcas com corrimentos.

Antibióticos devem ser adicionados aos diluidores do sêmen do varrão quando este for conservado através de refrigeração. No entanto, o melhor será aquele que possa reunir atributos como, permitir que o sêmen se conserve com boa qualidade, apresentar equilíbrio entre o efeito antimicrobiano e o 
MOUTINHO, E.P.M. et al. Efeito de diferentes antibióticos na composição do diluente, sobre a viabilidade do sêmen suíno refrigerado. PUBVET, Londrina, V. 5, N. 19, Ed. 166, Art. 1121, 2011.

efeito tóxico para as células espermáticas, além de ter menor custo de aquisição.

\section{CONCLUSÕES}

Os antibióticos Cloridrato de Ceftiofur e Sulfato de Estreptomicina demonstraram ser capazes de conferir uma melhor qualidade do sêmen refrigerado, enquanto que, o Sulfato de Gentamicina se mostrou ineficiente para garantir doses de sêmen com bom padrão de qualidade.

O antibiótico Sulfato de Gentamicina demonstrou ser o melhor antimicrobiano para prevenir a proliferação de bactérias em diluidores de sêmen suíno refrigerado.

\section{REFERÊNCIAS BIBLIOGRÁFICAS}

AAMDAL, J.; HOGSET, I.; FILSETH, O. Extirpation of the preputial diverticulum of boars used in artificial insemination. J. Am. Vet. Med. Assn., v.132, p.322, 1958.

ALMOND, G.; POOLPERM, P. Semen contamination and choosing antibiotics. In: Proceedings of the North Carolina Healthy Hogs Seminar, 1996. Disponível em: < http://mark.asci.ncsu.edu/HealthyHogs/book1996/book96 5.htm>Acesso em: 18/03/2010.

ALTHOUSE, G.C.; LU, K.G. Bacteriospermia in extended porcine semen. Theriogenology, v.63, p.573-584, 2005.

ALTHOUSE, G.C.; KUSTER, C.E.; CLARK, S.G. Field investigations of Bacterial contaminants and their effects on extended porcine semen. Theriogenology, v.53, p.1167-1176, 2000.

AMORIM, E.A.M.; GRAHAM, J.K.; SPIZZIRI, B.; MEYERS, M.; TORRES, C.A.A. Effect of cholesterol or cholesteryl conjugates on the cryosurvival of bull sperm. Cryobiology., v.58, p.210-214, 2009.

BAMBA K.; CRAN, D.G. Effects of treatment with butylated hydroxylotuene on the suceptibility of boar spermatozoa to cold stress and dilution. J. Reprod. Fert., v.95, p.69-77,1992.

BENNEMANN, P.E. Avaliação de doses inseminantes produzidas em central de inseminação artificial de suínos no Sul do Brasil e o efeito da contaminação bacteriana sobre a qualidade espermática. 1998.251f. Dissertação (Mestrado em Ciências Veterinárias) - Universidade Federal do Rio Grande do Sul, Porto Alegre, RS. 1998.

BORTOLOZZO, P.F.; WENTZ, I.; BENNEMANN, P.E. Processamento e armazenamento das doses inseminantes. In: Inseminação artificial na suinocultura tecnificada. Porto Alegre, Palloti, 2005, 185p. 
BORTOLOZZO F.P., WENTZ I. \& DALLANORA D. Avanços na inseminação artificial de suínos. In: Anais dos Encontros Técnicos ABRAVES-RS (Estrela, Brasil), p.1-20, 2002.

BORTOLOZZO, F.P. ; BENNEMANN, P.E.; WENTZ, I; CARDOSO, M.R.I. Avaliação de doses inseminantes produzidas em Centrais de Inseminação Artificial de suínos no sul do Brasil II. Qualidade espermática. Arq. Da Faculdade de Vet. Da UFRGS. v.28, n.2, 63 - 75, 2000.

BRAGA, C.S.R. Fertilidade de fêmeas suínas inseminadas com sêmen diluído e resfriado a $5^{\circ} \mathrm{C}$ ou $17^{\circ} \mathrm{C}$. Universidade Federal de MG, Escola de Veterinária, p. 23-41, 2007.

COELHO, N. M. Flora bacteriana do prepúcio e sêmen de reprodutores Bos Taurus. 1976. $56 \mathrm{f}$. Dissertação (Mestrado em Medicina Veterinária) - Escola de Veterinária, Universidade Federal de Minas Gerais, Belo Horizonte, 1976.

CORRÊA, M.N. Inseminação artificial em suínos. Pelotas: Editora UFPEL, p. 181, 2001.

DE LEEUW, F.E; CHEN, H.C.; COLENBRANDER, B.; VERKLEIJ, A.J. Colo-induced ultrastructural changes in Bull and boar sperm plasm membranes. Criobiology, v.27, p.171-83, 1990.

ERICH, L.G. A critique of ASTM Standard D1193. 2003. Disponível em:< http://www. highq.com/pdf/astmd1193critique.pdf>. Acesso em: 18/03/2010.

FERREIRA, F. M.; WENTZ, I.; SCHEID, I. R. Comportamento de monta e características seminais de suínos jovens landrace e large white. Ciência Rural, v. 35, p.131-137, 2005.

FLOWERS, W.L. Management of boards for efficient semen production. Journal of reproduction and fertility. Supplement 52, p.67-78, 1997.

FRASER I.; GORSZCZARUK K.; STRZEZEK J. Relationship between motility and membrane integrity of boar spermatozoa in media varying in osmolality. Reprod. Dom. Anim., v.36, p. 325-329, 2001.

FUNAHASHI, H.; SANO, T. Select antioxidants improve the function of extended boar sêmen stored at $10^{\circ} \mathrm{C}$. Theriogenology, v.63, p.1605-1616. 2005.

GADEA, J. Semen extenders used in the artificial insemination of swine. A review. Spanish J.

Agr. Res., v.1, n.2, p.17-27, 2003. Disponível em: <www.engormix.com /rate_list.asp?|=E\&art_id=87> acesso em: 18/03/2010.

GADELLA, B.M. Lipid changes in the plasma membrane of capacitating boar spermatozoa. Reprod. Dom. Anim., v.31, p.63-73, 1996.

GOPALKRISHNAN, K.; JOSEPH, R.; SHETH, A. R. Alteration of sêmen characterristics and regulatory factors in human semen with bacterial infection. Archives of Andrology, Bristol, $v$. 32, n. 3, p. 213-218, May/June, 1994.

GRAHAM, J.K., HAMMERSTEDT, R.H.,Differential effects of butylated hydroytoluene analogs on bull sperm subjected to cold-induced membrane stress. Cryobiology, v.29, p.106-117, 1992.

HAFEZ, E.S.E. Semen evaluation. In: Reproduction in farm animal. 6.ed. Philadelphia: Lea e Febier, 1993, p.405-423.

HAMMERSTEDT, R.H.; PARKS, J.E. Changes in sperm surfaces associated with epididymal transit. J. Reprod. Fert., Suppl., v.34, p.133-149,1987. 
HAMMERSTEDT, R.H. Maintenance of bioenergetic balance in sperm and prevention of lipid peroxidation a review of the effect on design of storage preservation systems. Reprod. Fertil. Dev., v.5,n.6, p.675-90, 1993.

HANCOCK, J. L.; HOWELL, G.J.R. The collection of boar semen. Vet. Rec., v.71, n.5, p.664$665,1959$.

HOLT, W.V. Fundamental aspects of sperm cryobiology: the importance of species and individual differences. Theriogenology, v.53, n.1, p.47-58, 2000.

JOHNSON, L.A.; WEITZE, K.F.; FISER, P. Storage of boar semen. Anim. Reprod. Sci., v.62, p.143-172, 2000.

KEMP, B.; SOEDE, N.M. Consequences of variation in interval from insemination to ovulation on fertilization in pigs. J. Reprod. Fert., Suppl., v.52, p.79-89, 1997.

LEVIS, D. Liquid boar semen production: Current extender technology and where do we go from here. In: INTERNATIONAL CONFERENCE ON BOAR SEMEN PRESERVATION. 4. 2000, Beltsville. Proc... Beltsville: 2000. p.121.

MARTIN-RILLO, S.; SEBASTIAN, J. J.; ALIAS, E.; DIASYUBERO, C. The effects of antibiotic associations in the conservation of boar semen at 15oC. In: XIII International Pig Veterinary Society, p.295, 1984.

MAZUROVA J, KRPATOVA J. The risks of the cryopreservation of bull semen. Veterinarstvi, V.40, p.402-404, 1990.

MCNITT, J.I; FIRST, N.L. Effect of 72 hours heat stress on sêmen quality in boars. International Journal of Biometrics. v.14, p. 373-380. 1970.

MOORE, A.I.; SQUIRES, E.L.; GRAHAM, J.K. Adding cholesterol to the stallion sperm plasma membrane improves cryosurvival. Cryobiology., v.51, p.241-249, 2005.

OLIVEIRA, E.C.S. Efeito de diferentes diluidores sobre a criopreservação do sêmen canino. Dissertação (Mestrado em Medicina Veterinária) - Escola de Veterinária, Universidade Federal de Minas Gerais, Belo Horizonte, 2003. MG.

PAQUIGNON, M. Freezing and Thawing extenders for boar spermatozoa. In: INTERNATIONAL CONFERENCE ON BOAR SEMEN PRESERVATION, I, p.129-146, 1985.

PERESTRELO-VIEIRA R, PERESTRELO-VIEIRA $\mathrm{H}$. Algumas notas sobre as doenças transmitidas pelo sêmen de suíno. Méd Vet, v.43, p.5-14, 1995.

POOLPERM, P. Factors influencing semen quality and fertility in boars. 2001, 156f. (Doctor of Philosophy, Animal Science). College of Veterinary Medicine, North Caroline State University, Raleigh, 2001.

PURDY, P.H., GRAHAM, J.K. Effect of adding cholesterol to bull sperm membranes on sperm capacitation, the acrosome reaction, and fertility. Biol. Reprod., v.71, p.522-527, 2004b.

PURSEL, V.G.; JOHNSON, L. A.; SCHULMAN, L.L. Interation of extender composition and incubation period on cold shock susceptibility of boar spermatozoa. J. Anin. Sci., v.35, n.3, p.580-584, 1972a. 
REIS, G.R.; CASTAGNA, C.D.; DIAS, C.P. Motilidade espermática e integridade de acrossoma de sêmen suíno resfriado com ou sem o uso de gentamicina. In: CONGRESSO BRASILEIRO DE VETERINÁRIOS ESPECIALISTAS EM SUÍNOS, 9, 1999, Belo Horizonte, Anais... Belo Horizonte: p.339-340, 1999.

RODRIGUES, A. L. R.; BICUDO, S. D.; LOPES, C.A.M. Sensibilidade de bactérias do sêmen de touros Nelore (Bos indicus) em central de inseminação artificial frente a antibióticos utilizados em meios diluidores. Revista Brasileira de Reprodução Animal, v. 25, n. 3, p. 267- 268, 1999.

RURANGWA, E.; KIME, D. E.; OLLEVIER, F.; NASH, J. P. The measurement of sperm motility and factors affecting sperm quality in cultured fish. Review article. Aquaculture, Amsterdam, v. 234, n. 1/4, p. 1-28, May 2004.

SCHEID, I.R. Aspectos de biossegurança e higiene associados a inseminação artificial em suínos. On Line. Concórdia, 2000. Disponível em www.cnpsa.embrapa.br/abravessc/ pdf/Memorias2000/5_Isabel.pdf. Acesso em 15/04/2010.

SISVAR - Sistema de análise de variância. SISVAR software, Versão 5.0, 2009.

SONE, M. Effects of various antibiotics on the control of bacterial in boar semen. The Veterinary Record, v. 111, p. 11-14, 1982.

SOUZA, A. F.; GUERRA, M. M. P.; COLETO, Z. F.; MOTA, R. A.; SILVA, L. B. G.; LEÃO, A. E. D. S.; SOBRINHO, E. S. N. Avaliação microbiológica do sêmen fresco e congelado de reprodutores caprinos. Braz. J. vet. Res. Anim. Sci. São Paulo, v. 43,n.3, p.329-336, 2006.

STONE, B.A. Heat induced infertility of boars: the interrelationship between depressed sperm output and stimulation of the critical air temperature above which sperm output is impaired. Animal Reproduction Science, v.4, p. 283-299.1982.

STOSS, J.; DONALDSON, E. M. Preservation of fish gametes. In: INTERNATIONAL SYMPOSIUM REPRODUCTION PHYSIOLOGY FISH, 1982, Wageningen. Proceedings... Wageningen, p. 114$122,1982$.

THIBIER, M.; GUERIN, B. Hygienic aspects of storage and use of semen for artificial insemination. Animal Reproduction Science, v. 62, p. 233-251, 2000.

VAN SHCIE, F.W. The use of antibiotics in boar semen extenders in the Netherlands. Reprod. Dom. Anim., v.31, suppl.1, p.323, 1996.

ZAHN, F.B. Efeito da incorporação de colesterol na membrana plasmática de espermatozóides sobre os parâmetros espermáticos e índice de fertilidade do sêmen congelado na espécie eqüina. 2002. 110p. Dissertação (Mestrado em Medicina Veterinária - Área de Reprodução Animal) - Faculdade de Medicina Veterinária e Zootecnia, Universidade Estadual Paulista UNESP, Botucatu - SP, 2002, 110p.

WALTZ, F. A.; FOLEY, C. W.; HERSCHLER, R. C.; TIFFANY, L. W.; LISKA, B. J. Bacteriological studies of boar semen. J. Anim. Sci., v. 27, p. 1357-1362, 1968.

WATSON, P.F.; ANDERSON, W.J. Influence of butylated hydroytoluene (BHT) on the viability of ram spermatozoa undergoing cold shock. J. Reprod. Fert., v.69, p.229-235, 1983. 
WATSON, P.F.; PLUMMER, J.M. The response of boar sperm membranes to cold shock and cooling. In: INTERNATIONAL CONFERENCE ON DEEP FREEZING OF BOAR SEMEN 1, 1985, Uppsala, Proc... Uppsala: 1985, p.113-125.

WEITZE, K. F. Transmissible disiases by artificial insemination in pigs. In: CONGRESSO PANAMARICANO DE CIÊNCIAS VETERINÁRIAS. 15. Campo Grande - MS. Associação Panamericana de Ciências Veterinárias. Abstracts, p. 1-7. 1996.

WEITZE, K.F. Long-term storage of exteded boar semen. In: INTERNATIONAL CONFERENCE ON BOAR SEMEN PRESERVATION, 2, 1990, Beltsville, Proc... Beltsville: p.231-253, 1990a. 